
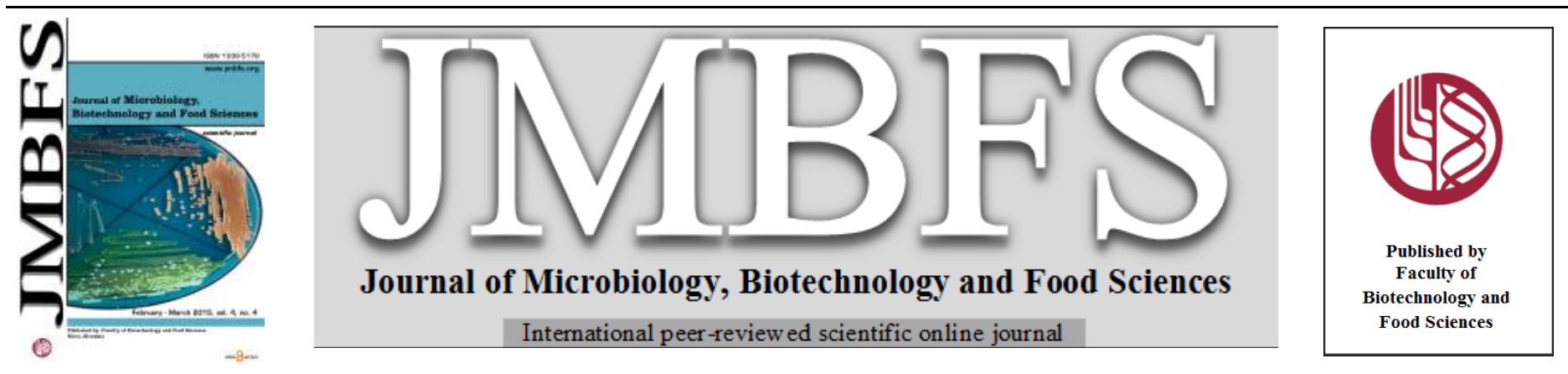

\title{
PHYSICOCHEMICAL CHARACTERISTICS, FATTY ACID COMPOSITION AND NUTRITIONAL EVALUATION OF FOUR MINOR OILS
}

\section{B. Mondal}

\author{
Address(es): \\ Chemistry Department, B.N.Mahavidyalaya, Itachuna, Hooghly-712147, WB, India, Phone: +919474778062.
}

*Corresponding author: bmondal.bnm@gmail.com

doi: 10.15414/jmbfs.2015.4.4.301-305

ARTICLE INFO

Received 5. 8. 2013

Revised 21. 11. 2014

Accepted 27. 11. 2014

Published 1.2. 2015

Regular article

open ${ }_{\text {Aackess }}$

\begin{abstract}
Four minor seed oils from Abroma augusta (AA), Annona squamosa (AS), Bombax ceiba (BC) and Ceiba pentandra (CP) plants were refined and refined seed oils were analyzed for their physicochemical properties. All the refined seed oils had normal physicochemical characteristics. The seed oils except $\mathrm{CP}$ also had usual fatty acid composition and contained a higher proportion of unsaturated fatty acids namely linoleic and oleic, a suitable criterion of edibility of vegetable oils. In addition to normal fatty acids, the refined CP seed oil also contained $10.6 \%$ cyclopropenoid fatty acids (CPFA), therefore, is not recommended as a dietary source of fat unless a suitable method is developed for its removal or detoxification. Nutritional evaluation of the refined seed oils were carried out in rats by feeding the respective oils and peanut oil as control at $10 \%$ level in a $20 \%$ protein diet with adequate vitamins and minerals. The refined CP seed oil showed poor growth performance, low FER, altered lipid metabolism and histopathological abnormalities in the liver which indicate the unsuitability of it for edible purpose. Growth performances, FER, serum and liver lipids, organ weights and histopathological findings of other three minor oils were satisfactory and comparable to that of peanut oil, therefore, they can be considered for edible use
\end{abstract}

Keywords: Abroma augusta, Annona squamosa, Bombax ceiba, Ceiba pentandra, minor seed oils, fatty acid composition, nutritional evaluation

\section{INTRODUCTION}

In recent years, much attention has been paid all over the world to search new sources of oils to meet up the gap between demand and inadequate supply of edible oils. Oils and fats obtained from nontraditional sources specially tree origin are used for human consumption as well as in industry by soap, paint, varnish, hair oil and lubricant manufacturing units in limited areas where they are grown and known as minor oils. India has plenty of oilseed bearing perennial trees from which more than one million ton of minor oils can be obtained (SubCommittee on Minor Oilseeds, 1971; Editorial, 1977) but hardly 7\% of the total potential is being tapped (Vimal and Naphade, 1980). One of the main problems in the fuller utilization of minor oils is inadequate scientific information on their chemical, nutritional and toxicological properties. Apart from the utilization of the minor oils, in general, primarily as edible ones for human consumption or as non-edible grades in industries, recent studies have shown that they may be profitably used as raw materials for biodiesel production if their physicochemical properties are suitable (Achten et al., 2008; Divakara et al., 2010; Natarajan and Karthick, 2012). This emphasizes the need to search newer sources of minor oils which are not evaluated adequately on the basis of their chemical and nutritional properties. In our laboratory, we have been studying in this field since 1984 ( Mondal et al., 1984a; Mondal et al., 1984b; Mondal and Ghosh Majumdar, 1984; Mondal et al., 1985a; Mondal et al., 1985b; Maity and Mondal, 1990; Mondal and Maity, 1991; Mondal and Maity, 1992) and in this journey of searching on lesser known oilseeds, I have come across four plant species.

Abroma augusta Linn. (Sterculiaceae), a quick growing shrub was used to cultivate earlier in India for a fibre obtained from the stem. The fibre is suitable for mixing with jute in the manufacture of hessian, cordage, matting, fishing-lines and nets, pouches and dyed false hair etc. (CSIR, 1985). The commercial cultivation of that plant as fibre crop has now been reduced but today its versatile medicinal applications have kept its growth intact in India. At present, it is widely used in Ayurvedic system of medicine not only in India but in Bangladesh, Pakistan and some other Asian and African countries especially for the treatment of uterine and menstruation disorders, gonorrhea, diabetes, rheumatic joint pain, headaches with sinusitis, dermatitis and cancer (Aguilar $\boldsymbol{e t}$ al., 2003; Gupta et al., 2011; Nahar et al., 2010). Mainly the fresh viscid sap of the root bark, whole root, fresh leaves, leaf juice and whole plant are used in the preparation of herbal formulations. A study showed that the seed oil possesses pharmacological properties including phytotoxic and antifungal activities (Khan et al., 2003). However, no research data on the chemical composition of the seed oil and its nutritional evaluation are available in the literature.

Annona squamosa Linn. (Annonaceae), a small tree (2-3 m height), popularly known as custard-apple is cultivated largely for its fruit in Indian subcontinent, China, Philippines, Egypt and some African countries like Cameroon, Nigeria and Sudan. Spontaneously multiplying wild varieties are also abundantly found in those countries where it is cultivated. The plant (root, stem bark, leaves, green fruit and seed) is reported to contain several glycosides, alkaloids, saponins, flavonoids, phenolic compounds and phytosterols (Pandey and Barve, 2011) and often used in folkloric medicine for the treatment of several diseases including cardiac disease, diabetes, hyperthyroidism, diarrhea, dysentery, cold, urine infections and cancer (Pandey and Barve, 2011; Saha, 2011; Vidyasagar and Singh, 2012; Chen et al., 2012). Custard-apple is one of the best tropical fruits for which it is usually cultivated. Its soft pulp is most delicious and eaten as such or used in making of ice creams and milk beverages. Blackish fruit seeds are non-edible mainly due to presence of a toxic alkaloid, anonaine (Pandey and Barve, 2011), therefore, large amount of it remains waste practically without any application. Sometimes powdered seeds are traditionally used as fish poisoning and insecticides. A paste of the seed powder is locally applied to the head to kill lice. The seed contain $27.5 \%$ fatty oil and the fatty acid composition of the seed oil is reported (Mariod et al., 2010; Mariod et al., 2011). The possibility of using Annona seed oil as a source of biodiesel is also investigated (Branco et al., 2010; Masruri et al., 2012). However, chemical and nutritional evaluation of the seed oil is still worthy so as to promote its better and fuller utilization.

Bombax ceiba Linn. (Bombacaceae), a lofty deciduous tree, grown up to $40 \mathrm{~m}$ in height is widely planted in India, Bangladesh, Indonesia and other parts of tropical and subtropical Asia, Australia and Africa for Kapok of commerce. According to Ayurveda, it is a famous medicinal plant and has stimulant, astringent, haemostatic, diuretic, antidiarrhoeal, cardiotonic, emetic, antidysenteric and antipyretic properties (Singh and Panda, 2005; Verma et al., 2011; Anandarajagopal et al., 2013). The trees bear fruits of woody five-valved capsule which open when ripe and produce white fibres or floss like cotton. Inside the floss, there are numerous black seeds, so during collection of floss, 
seeds are separated mechanically or manually by beating. The seeds so obtained in huge amount as by products are considered waste material and unused (Jain $\boldsymbol{e t}$ al., 2009). One mature tree gives on an average 1000 fruits that yield nearly $6 \mathrm{~kg}$ floss and $5 \mathrm{~kg}$ seeds. It is reported that the seeds contain $23.5 \%$ oil and major fatty acid components are linoleic, oleic and palmitic (Arafat et al., 2011) Considering the total potential of seed production, its commercial exploitation as newer source of oil might be considered for which the seed need to be evaluated for its chemical and nutritional properties.

Ceiba pentandra (Bombacaceae), an elegant tree, 20-30 $\mathrm{m}$ in height, is available throughout the hotter parts of India and African countries in commercial quantities. It resembles $B$. ceiba and is considered most important as a source of Kapok fibre obtained from the floss derived from the inner fruit wall. Past and modern day herbalists recommend various parts of the tree for a wide range of medical applications, in the treatment of colds, coughs, fever, headache, leprosy, diarrhea, dysentery, dysmenorrhea, hypertension, stomach problems, hernia, gonorrhea, edema asthma and rickets (Elumalai et $\boldsymbol{a l . , ~ 2 0 1 2 ; ~ F r i d a y ~ e t ~ a l . ~}$ 2011). The seeds of $C$. pentandra are available largely as waste by-products during collection of its floss as that of $B$. ceiba. The oil content of the seed is in the range $20-25 \%$ and the seed oil is rich in linoleic acid followed by palmitic and oleic acid (Salimon and Kadir, 2005). The possibility of using B. ceiba seed oil as a raw material for biodiesel production is also investigated (Norazahar $\boldsymbol{e}$ al., 2012). As the fatty acid composition of the seed oil resembles that of cotton seed oil, therefore, its chemical and nutritional evaluation is highly needed.

\section{MATERIAL AND METHODS}

\section{Samples, Solvents and Reagents}

Dried seeds of Bombax ceiba (BC) and Ceiba pentandra (CP) were collected locally in the month of May (2012) when they were abundantly available. Annona squamosa (AS) seeds were also collected locally in the month of September while Abroma augusta (AA) seeds were purchased from a local Aurvedic shop and identification was confirmed by Prof. A. Bhattacharyay, Botany Department, Burdwan University, Burdwan, WB, India.

All the solvents as well as chemicals were of analytical grade, procured from $\mathrm{M} / \mathrm{S}$, Merck India Ltd., and used in the study without further purification.

\section{Extraction of Seed Oil}

The dried seeds were pulverized into powder and extracted with petroleum ether $\left(40-60{ }^{\circ} \mathrm{C}\right.$ ) in a soxhlet apparatus for 72 hours. The solvent was evaporated at low temperature under reduced pressure in rotary evaporator to obtain the seed oil. The oil content was expressed as a percentage of the extracted oil to the sample weight $(\mathrm{w} / \mathrm{w})$. The oil obtained so far was stored separately in a dark glass bottle in cold $\left(4^{\circ} \mathrm{C}\right)$.

Refining and Physicochemical Analysis of the Seed Oil

All the seed oils had unusual color like brown, reddish yellow and pale yellow, so, they were decolorized by treating with Fuller's earth, activated carbon and charcoal and subsequent filtration to get the palatable color. Neutralization of the decolorized seed oils were done by treating with boric acid, sodium bisulphate and dilute $\mathrm{NaOH}$ solution whenever necessary.

The physicochemical constants of the refined seed oils like specific gravity, refractive index, iodine value, acid value, saponification value and unsaponifiable matter were determined according to the Official and Tentative Methods of the AOCS (1993). The oils were examined for ultraviolet (UV) absorption in $\mathrm{CCl}_{4}$ on a Beckman 26 UV-Visible spectrophotometer and for infrared (IR) absorption in $\mathrm{KBr}$ disc using a Beckman Model $221 \mathrm{IR}$ spectrophotometer. The refined seed oils as well as their fatty acid methyl esters were also examined for the presence of hydroxyl, epoxy and cyclopropenoid fatty acids following turbidity (Lakshminarayana, 1968), picric acid (Fioriti et al., 1966) and Halphen (Magne, 1965) tests respectively.

\section{Fatty Acid Analysis}

The fatty acid composition of the seed oils were determined by gas liquid chromatography (GLC). The refined seed oils were converted to their corresponding methyl esters by refluxing with methanol containing $1.0 \%$ sodium methoxide following the method described earlier (Mondal and Ghosh Majumdar, 1984). It was found by Halphen test (Magne, 1965) that the CP seed oil contains cyclopropenoid fatty acids for which methyl esters of it were treated with anhydrous methanol saturated with silver nitrate for $20 \mathrm{hr}$ at ambident temperature to convert esters into stable ether and keto derivatives for GLC analysis. Thin-layer chromatography (TLC) of methyl esters was carried out on Silica gel $\mathrm{G}$ using n-hexane, diethyl ether and acetic acid (80:19:1 v/v/v). GLC analysis of the fatty acid methyl esters (FAME) was performed using a Perkin Elmer F 11 gas chromatograph (GLC) fitted with a flame ionization detector. The carrier gas was nitrogen with a flow rate of $30 \mathrm{~mL}$ per minute. The stationary phase was a glass column $(1.8 \mathrm{~m} \mathrm{X} 6 \mathrm{~mm})$ containing $15 \%$ DEGS coated on 100 120 mesh chromosorb 'W'. The temperature of the column was maintained at $200{ }^{\circ} \mathrm{C}$ throughout the analysis. The injection port and detector were maintained at $250{ }^{\circ} \mathrm{C}$ and $300{ }^{\circ} \mathrm{C}$ respectively. The chart speed one centimeter per minute and attenuation $\left(16 \times 10^{-10}\right)$ were also suitably maintained. The peaks obtained by injecting the FAME of the oil samples under study were identified by running a mixture of standard FAMEs (Sigma Chemicals, Germany). Areas of the triangular Gaussian peaks were measured and they were summed up to find the percent distribution of individual fatty acids.

\section{Nutritional Evaluation of the Refined Seed oils}

Sixty albino rats of local strain (inbred in our laboratory) age 1 month and weighing about 60-70 $\mathrm{g}$ of either sex were divided into five groups of 12 animals each and individually caged. Four groups were used as experimental and fed on diet containing $10 \%$ refined seed oils while other group of 12 rats receiving $10 \%$ peanut oil in the diet served as control. One refined seed oil was used exclusively for all the twelve animals of a experimental group and in this way 4 seed oils were assigned to 4 groups. Besides oil, the composition of the diet of both experimental and control groups was same as used in our earlier study (Mondal et al., 1982). The animals were fed on their respective diets and water ad libitum for 12 weeks. Food intake was recorded daily and the animals weighed twice weekly. Feed efficiency ratios (FER), which represent the weight gain per unit food intake, were calculated. Digestibility of the oils was determined from the data of oil intake and oil excreted through urine and feces.

At the end of experimental period of 12 weeks, the rats of the both experimental and control groups were sacrificed, blood and livers were collected and tota lipids, phospholipids, total cholesterol, triglycerides and FFA were determined following the conventional methods as described in one of our earlier study (Mondal and Maity, 1983). The key organs such as liver, heart, kidney, spleen and reproductive organs were weighted and examined microscopically for histopathology. Statistical analysis of the data was done by Student t-test.

\section{RESULTS AND DISCUSSION}

\section{Refining}

Data on crude oil content of the minor oilseeds as well as yield after refining are presented in Table 1. All the plant seeds had appreciable oil content but the crude seed oils had an undesirable color, high acid value and high unsaponifiable matter. In fact, minor oils are usually characterized by deep color and high contents of free fatty acids and non-lipid components as unsaponifiable matter which limits their use in the raw state. One of the crude seed oils, AS contained alkaloid at the level of $0.1 \%$ as evidenced by chemical test. The crude seed oils were refined on a laboratory scale by trial and error methods following the principles recommended by AOCS (1993). All the refined seed oil had a palatable color like that of mustard oil. Refining loss was comparatively lower with an appreciable final yield. Refined AS oil was found to be devoid of alkaloid.

\section{Physicochemical Properties}

The physicochemical properties of the refined seed oils are presented in Table 2 . Among the four minor oils, AA showed comparatively higher values for specific gravity, refractive index and saponification value but the values are within the safe limit for edible vegetable oils according to Indian (IS, 1984) and Codex standards (FAO/WHO, 2009). The AU oil had a high saponification and iodine value which indicate that it is semidrying type. It was found that the refining of the seed oil reduced the acid value remarkably; for AA it was reduced from 7.5 (for crude one) to 1.5, for AS from 6.8 to 0.8 , for $\mathrm{BC}$ from 8.4 to 2.1 and for $\mathrm{CP}$ from 6.4 to 1.7 . All the refined seed oils had low unsaponifiable matter in the range of $0.61-1.41$, a good criterion for their edibility. TLC of the unsaponifiable matter of the refined seed oils on Silica gel $G$ using a solvent system of benzene:ethyl acetate $(95: 5 \mathrm{v} / \mathrm{v})$ did not reveal any unusual constituents. Each of the refined seed oils gave a negative response for Fioriti's picric acid test (1966) indicating the absence of epoxy fatty acids in the refined seed oils. The sulphuric acid turbidity test (Lakshminarayana, 1968) as well IR spectra did not show the presence of hydroxyl fatty acids in the refined seed oils. Among the four seed oils, AA, AS and BC responded negatively to the qualitative test for CPFA and their IR spectra did not show any characteristic band of the cyclopropenoid moiety while $\mathrm{CP}$ gave a positive response for the Halphen test as well as an IR spectra band at $1008 \mathrm{~cm}^{-1}$ confirming the presence of CPFA in it. The UV and IR spectra of the refined seed oils or their methyl esters did not show the presence of either trans or conjugated unsaturation.

\section{Fatty acid composition}

The fatty acid composition of the four refined seed oils obtained by GLC analysis is shown as percent of total methyl esters in Table 3. Linoleic acid was predominant $(68.2 \%)$ in AA seed oil, followed by palmitic $(13.8 \%)$ and oleic $(10.0 \%)$. The AA seed oil also contained $4.1 \%$ linolenic and $3.9 \%$ stearic acids The major fatty acids in AS seed oil were oleic $(52.4 \%)$, linoleic $(19.6 \%)$, palmitic $(12.4 \%)$ and stearic $(8.6 \%)$. Simultaneously it contained arachidic 
(4.3\%), linolenic $(1.5 \%)$ and myristic $(1.2 \%)$ acids. Mariod et al 2010; 2011) reported 50.5, 22.7, 15.2, 9.3 and $1.5 \%$ for oleic, linoleic, palmitic, stearic and arachidic acids respectively in AS seed oil. This difference in fatty acid composition of AS seed oil may be attributable to varietal differences as well as differences in agronomic conditions under which the plants are grown. The major fatty acid components in BC were oleic $(62.0 \%)$ and palmitic $(24.8 \%)$ followed by linoleic $(8.2 \%)$, arachidic $(2.8 \%)$ and myristic $(2.2 \%)$. The fatty acid composition of BC seed oil obtained in the present study does not significantly differ from that reported earlier (Arafat et al., 2011). The $\mathrm{CP}$ seed oil was rich in linoleic $(37.2 \%)$, oleic $(25.6 \%)$ and palmitic $(22.4 \%)$ acids followed by stearic $(2.7 \%)$, linolenic $(1.0 \%)$ and myristic $(0.5 \%)$ acids. This result was somewhat different from that reported by Sarkiyayi et al (2009) who reported 42.6, 20.9, 20.8, 13.7 and 1.9\% for linoleic, palmitic, oleic, stearic and linolenic acids respectively in $\mathrm{CP}$ seed oil. The refined $\mathrm{CP}$ seed oil contained an appreciable amount $(10.6 \%)$ of CPFA in which malvalic acid $(7.5 \%)$ was more predominan than sterculic $(3.1 \%)$. Surprisingly Sarkiyayi et al (2009) did not note the presence of CPFA, Salimon \& Kadir (2005) on the other hand reported 10-12\% CPFA in CP seed oil. All the four refined seed oils studied so far contained a higher proportion of unsaturated fatty acid at the level of $82.3 \%$ for AU, 77.8 for AS, $73.0 \%$ for BC and $63.8 \%$ for CP similar to the commonly used vegetable oils

\section{Nutritional evaluation}

The growth performances and the FER in both the control fed $10 \%$ peanut oil diet and experimental groups fed $10 \%$ refined seed oil diets were calculated for 12 weeks. Results are presented in Table 4. The animals of experimental groups gained less weight than controls and the lowest value was observed for the animals fed CP seed oil. The value for FER was significantly lower in the group of rats fed CP seed oil as compared to those fed peanut oil, although FER of othe three experimental groups were somewhat lower but did not differ significantly with that of peanut oil. The values for digestibility were $90,89,91$ and $82 \%$ for AA, AS, BC and CP seed oils respectively compared to $94 \%$ for peanut oil. Thus, the nutritional quality of the refined seed oils (except CP) appears to be satisfactory on the basis of their digestibility, growth performances and FER. Additionally AS and BC had a very high content of oleic acid (MUFA) which is nutritionally favourable for health as MUFA reduces the risk of coronary artery disease by decreasing serum cholesterol (Covas, 2007; Covas et al., 2009).

Organ weights of the rats fed either peanut oil or refined seed oils for 12 weeks at the time of sacrifice, expressed as percentage of body weight are shown in Table 5 . The results revealed no significant difference in organ weights between control and experimental animals except for those fed CP seed oil. Liver, heart and testis/ovary weights of rats fed CP seed oil were significantly higher than the corresponding values obtained for the controls.

Lipid profile of serum and liver of rats were measured at the time of sacrifice after 12 weeks of feeding either peanut oil or refined seed oil diets and are presented in Table 6. The group of rats fed AA, AS and BC seed oils did not differ significantly with regard to a variety of serum and liver lipid parameters as compared to those fed peanut oil. On the other hand, total lipids, total cholestero and triglycerides of serum and liver and serum FFA of rats fed CP seed oil were significantly higher compared to the corresponding values for controls. The results on lipid biochemistry indicate altered lipid metabolism in the animals fed CP seed oil.

Histopathological examination of the various organs did not reveal any significant abnormalities in the rats fed refined seed oils except CP seed oil Some histopathological changes including mild to moderate degree of fatty infiltration were noted in the liver of rats fed CP seed oil.

Adverse effects of feeding pure CPFA are well documented (Shone, 1966) Morphological changes in the liver due to lipid accumulation, increased liver weight and reduction in mixed function oxidase system were also recorded in literature (Lee et al., 1971). Previous study by Lee and others (1971) showed that CPFA can act as a carcinogen in rainbow trout fed aflatoxin. On the contrary, beneficial role of CPFA in obesity has recently been reported (Ortinau $\boldsymbol{e t}$ al. 2013). In fact, CPFA inhibit the desaturases and hence the stearic $\rightarrow$ oleic $\rightarrow$ linoleic $\rightarrow$ arachidonic pathway is inhibited - a probable reason for altered lipic metabolism.

Thus, poor growth performance and altered lipid metabolism in rats fed $10 \% \mathrm{CP}$ seed oil are probably due to presence of CPFA in the oil. Similar results had also been reported after feeding Hibiscus sabdariffa seed (Mukhtar, 2007) and seed oil (Rukmini et al., 1982) both of which contain CPFA. On the contrary, Ari and coworkers (2011) showed good growth performance of Broilers fed $\mathrm{CP}$ seed based diet.

Table 1 Yield $(\mathrm{g} / 100 \mathrm{~g})^{\mathrm{a}}$ and color of the crude and refined seed oils

\begin{tabular}{|c|c|c|c|c|c|}
\hline \multirow{2}{*}{ Seed oils } & \multicolumn{2}{|c|}{ Crude oil } & \multicolumn{2}{|c|}{ Refining } & \multirow{2}{*}{ Yield of refined oil } \\
\hline & Yield & Color & Decolorization & Neutralisation & \\
\hline AA & $19.8 \pm 0.2$ & Light brown & $\begin{array}{l}\text { Fuller's earth and } \\
\text { filtration }\end{array}$ & $\mathrm{NaHSO}_{3}$ solution & $18.2 \pm 0.5$ \\
\hline AS & $39.2 \pm 0.4$ & Reddish brown & $\begin{array}{l}\text { Fuller's earth and } \\
\text { filtration }\end{array}$ & $0.1 \mathrm{M} \mathrm{NaOH}$ solution & $36.8 \pm 0.2$ \\
\hline $\mathrm{BC}$ & $20.1 \pm 0.3$ & Pale yellow & $\begin{array}{l}\text { Activated carbon and } \\
\text { filtration }\end{array}$ & $\mathrm{H}_{3} \mathrm{BO}_{4}$ solution & $18.8 \pm 0.5$ \\
\hline $\mathrm{CP}$ & $28.5 \pm 0.2$ & Pale yellow & Charcoal and filtration & $0.05 \mathrm{M} \mathrm{NaOH}$ solution & $26.2 \pm 0.4$ \\
\hline
\end{tabular}

are carried out in triplicate and values are expressed as mean \pm standard deviation, AA Abroma augusta, AS Annona squamosa, BC Bombax ceiba, CP Ceiba pentandra

Table 2 Physicochemical properties of the refined seed oils ${ }^{\mathrm{a}}$

\begin{tabular}{|c|c|c|c|c|}
\hline \multirow{2}{*}{ Physicochemical constants } & \multicolumn{4}{|l|}{ Refined seed oils } \\
\hline & AA & AS & $\mathrm{BC}$ & $\mathrm{CP}$ \\
\hline Specific gravity & $0.9046 \pm 0.01$ & $0.8236 \pm 0.02$ & $0.8643 \pm 0.01$ & $0.8425 \pm 0.02$ \\
\hline Refractive index & $1.4701 \pm 0.0026$ & $1.4625 \pm 0.0024$ & $1.4610 \pm 0.0032$ & $1.4606 \pm 0.0042$ \\
\hline Iodine value & $125.5 \pm 1.5$ & $103.2 \pm 1.3$ & $98.4 \pm 1.6$ & $102.5 \pm 2.1$ \\
\hline Acid value & $1.5 \pm 0.01$ & $0.8 \pm 0.02$ & $2.1 \pm 0.02$ & $1.7 \pm 0.03$ \\
\hline Saponification value & $285.2 \pm 1.6$ & $190.1 \pm 2.2$ & $196.6 \pm 1.2$ & $206.6 \pm 2.1$ \\
\hline Unsaponifiable matter $(\%, \mathrm{w} / \mathrm{w})$ & $1.41 \pm 0.01$ & $0.94 \pm 0.01$ & $1.01 \pm 0.02$ & $0.61 \pm 0.01$ \\
\hline Turbidity test & - & - & - & - \\
\hline Picric acid test & - & - & - & - \\
\hline Halphen test & - & - & - & + \\
\hline
\end{tabular}

${ }^{a}$ All determinations were carried out in triplicate and values are expressed as mean \pm standard deviation

AA Abroma augusta, AS Annona squamosa, BC Bombax ceiba, CP Ceiba pentandra; - negative, + positive 
Table 3 Fatty acid (FA) composition (\%) of the refined seed oils

\begin{tabular}{lcccc}
\hline FA $(\%)$ & AA & AS & BC & CP \\
\hline Myristic C14:0 & - & 1.2 & 2.2 & 0.5 \\
\hline Palmitic C16:0 & 13.8 & 12.4 & 24.8 & 22.4 \\
\hline Stearic C18:0 & 3.9 & 8.6 & - & 2.7 \\
\hline Oleic C18:1 & 10.0 & 52.4 & 62.0 & 25.6 \\
\hline Linoleic C18:2 & 68.2 & 19.6 & 8.2 & 37.2 \\
\hline Linolenic C18:3 & 4.1 & 1.5 & - & 1.0 \\
\hline Arachidic C20:4 $^{\text {Malvalic (C18:CPFA) }}$ & - & 4.3 & 2.8 & - \\
\hline Sterculic (C19:CPFA) & - & - & - & 7.5 \\
\hline SFA & - & - & - & 3.1 \\
\hline MUFA & 17.7 & 22.2 & 27.0 & 25.6 \\
\hline PUFA & 10.0 & 52.4 & 62.0 & 25.6 \\
\hline CPFA & 72.3 & 25.4 & 11.0 & 38.2 \\
\hline A & - & - & - & 10.6 \\
\hline
\end{tabular}

${ }^{a}$ Average of 3 samples

${ }^{\mathrm{b}}$ Ether plus keto derivatives

SFA saturated fatty acids, MUFA monounsaturated fatty acids, PUFA polyunsaturated fatty acids, CPFA cyclopropenoid fatty acids AA Abroma augusta, AS Annona squamosa, BC Bombax ceiba, CP Ceiba pentandra
Table 4 Growth rate and digestibility of the refined seed oils for 12 weeks $^{\mathrm{a}}$

\begin{tabular}{lccc}
\hline Source of oil & $\begin{array}{c}\text { Gain in body wt in } \mathrm{g} \\
\text { (at 84 days) }\end{array}$ & FER $^{\mathrm{b}}$ & $\begin{array}{c}\text { Digestibility of the } \\
\text { refined seed oils } \\
(\%)\end{array}$ \\
\hline Peanut & $126.4 \pm 10.2$ & $22.5 \pm 1.1$ & 94 \\
\hline AA & $120.5 \pm 8.32$ & $21.2 \pm 1.6$ & 90 \\
\hline AS & $121.3 \pm 7.5$ & $21.4 \pm 1.2$ & 89 \\
\hline BC & $123.6 \pm 8.3$ & $21.8 \pm 1.1$ & 91 \\
\hline CP & $100.4 \pm 5.6$ & $17.4 \pm 1.0^{*}$ & 82 \\
\hline
\end{tabular}

${ }^{\mathrm{a}}$ Values are expressed as mean \pm standard deviation for 12 animals

${ }^{\mathrm{b}}$ FER (feed efficiency ratio) body wt gain/food intake wt X 100

Levels of significance with respect to peanut group " $\mathrm{p}<0.05$

AA Abroma augusta, AS Annona squamosa, BC Bombax ceiba, CP Ceiba pentandra

Table 5 Organ weights (as \% body wt) ${ }^{\mathrm{a}}$ of rats fed refined seed oils for 12 weeks

\begin{tabular}{lccccc}
\multirow{2}{*}{ Organs } & \multicolumn{2}{l}{ Oil source } & \multicolumn{2}{l}{} \\
\cline { 2 - 6 } & Peanut & AA & AS & BC & CP \\
\hline Liver & $3.51 \pm 0.04$ & $3.84 \pm 0.05$ & $3.78 \pm 0.02$ & $3.91 \pm 0.06$ & $4.51 \pm 0.04^{*}$ \\
\hline Kidney & $0.64 \pm 0.06$ & $0.71 \pm 0.04$ & $0.72 \pm 0.03$ & $0.69 \pm 0.02$ & $0.81 \pm 0.06$ \\
\hline Spleen & $0.21 \pm 0.04$ & $0.24 \pm 0.05$ & $0.22 \pm 0.06$ & $0.23 \pm 0.04$ & $0.24 \pm 0.07$ \\
\hline Heart & $0.31 \pm 0.03$ & $0.34 \pm 0.11$ & $0.32 \pm 0.08$ & $0.33 \pm 0.09$ & $0.43 \pm 0.05^{*}$ \\
\hline Testis $^{\mathrm{b}}$ & $0.94 \pm 0.12$ & $0.96 \pm 0.07$ & $0.94 \pm 0.10$ & $0.95 \pm 0.08$ & $1.45 \pm 0.06^{* *}$ \\
\hline Overy $^{\mathrm{c}}$ & $0.67 \pm 0.07$ & $0.71 \pm 0.09$ & $0.68 \pm 0.06$ & $0.66 \pm 0.04$ & $0.95 \pm 0.05^{*}$ \\
\hline
\end{tabular}

${ }^{\mathrm{a}}$ Values are expressed as mean \pm standard deviation for 12 animals

${ }^{\mathrm{b}}$ For males, 6 in peanut group, 5 in AA, 4 in AS, 7 in BC, 5 in CP

${ }^{\mathrm{c}}$ For females, 6 in peanut group, 7 in AA, 8 in AS, 5 in BC, 7 in $\mathrm{CP}$

Levels of significance with respect to peanut group ${ }^{*} \mathrm{p}<0.05,{ }^{* *} \mathrm{p}<0.01$

AA Abroma augusta, AS Annona squamosa, BC Bombax ceiba, CP Ceiba pentandra

Table 6 Serum and liver lipids of rats fed refined seed oils for 12 weeks $^{\mathrm{a}}$

\begin{tabular}{|c|c|c|c|c|c|}
\hline \multirow{2}{*}{ Parameters studied } & \multicolumn{5}{|l|}{ Oil source } \\
\hline & Peanut & AA & AS & $\mathrm{BC}$ & $\mathrm{CP}$ \\
\hline \multicolumn{6}{|l|}{ Serum } \\
\hline Total lipids (mg/dL) & $280.4 \pm 8.4$ & $261.2 \pm 6.5$ & $289.2 \pm 6.3$ & $274.8 \pm 5.8$ & $348.6 \pm 5.1^{* *}$ \\
\hline Phospholipids (mg/dL) & $84.3 \pm 3.6$ & $86.8 \pm 2.4$ & $80.4 \pm 2.8$ & $87.1 \pm 2.3$ & $85.4 \pm 3.1$ \\
\hline Total cholesterol (mg/dL) & $75.4 \pm 2.6$ & $68.3 \pm 3.6$ & $74.1 \pm 4.1$ & $69.6 \pm 3.4$ & $108.8 \pm 2.5^{*}$ \\
\hline Triglycerides (mg/dL) & $35.2 \pm 1.2$ & $28.2 \pm 2.4$ & $36.1 \pm 2.4$ & $34.3 \pm 2.6$ & $54.9 \pm 1.3^{* *}$ \\
\hline FFA (mmol/L) & $0.35 \pm 0.04$ & $0.38 \pm 0.05$ & $0.41 \pm 0.02$ & $0.36 \pm 0.04$ & $0.58 \pm 0.03^{*}$ \\
\hline \multicolumn{6}{|l|}{ Liver } \\
\hline Total lipids (mg/g) & $138.9 \pm 4.4$ & $126.6 \pm 4.2$ & $140.0 \pm 4.1$ & $134.8 \pm 3.3$ & $186.4 \pm 3.1^{*}$ \\
\hline Phospholipids (mg/g) & $78.6 \pm 1.6$ & $74.9 \pm 2.1$ & $75.6 \pm 2.2$ & $81.3 \pm 2.5$ & $80.8 \pm 1.9$ \\
\hline Total cholesterol (mg/g) & $6.9 \pm 0.4$ & $6.3 \pm 0.5$ & $7.1 \pm 0.3$ & $6.8 \pm 0.4$ & $12.8 \pm 0.2^{*}$ \\
\hline Triglycerides $(\mathrm{mg} / \mathrm{g})$ & $28.4 \pm 0.5$ & $24.2 \pm 0.7$ & $26.2 \pm 1.1$ & $27.2 \pm 1.2$ & $46.7 \pm 0.4^{* *}$ \\
\hline FFA (mg/g) & $3.5 \pm 0.05$ & $3.8 \pm 0.08$ & $3.3 \pm 0.06$ & $3.9 \pm 0.08$ & $4.6 \pm 0.09$ \\
\hline
\end{tabular}

\section{CONCLUSION}

It is revealed from the results of the present study that Abroma augusta (AA), Annona squamosa (AS), Bombax ceiba (BC), and Ceiba pentandra (CP) seeds contain considerable amount of oil and seed oils can be refined traditionally with low refining loss. The physicochemical properties of the refined seed oils are more or less similar and comparable to most common vegetable oils like groundnut, sunflower and cotton seed. Fatty acid composition of the refined seed oils is determined by GLC. Major fatty acids are found to be linoleic $(68.2 \%)$, palmitic (13.8\%) and oleic (10.0\%) in AA seed oil. In AS seed oil predominant fatty acid is oleic $(52.4 \%)$ followed by linoleic $(19.6 \%)$ and palmitic $(12.4 \%)$. BC seed oil contains higher percentage of oleic $(62.0 \%)$ along with considerable amount of palmitic $(24.8 \%)$ and linoleic $(8.2 \%)$ acids. In CP, the major fatty acids of the oil are found to be linoleic $(37.2 \%)$, oleic $(25.6 \%)$ and palmitic (22.4\%). The CP seed oil also contains $10.6 \%$ CPFA, of which malvalic acid is more predominant than sterculic acid. It is noted from the results of nutritional evaluation by well established rat bioassay procedure that the refined seed oil based diets show good growth performances and FER, normal serum and liver lipids and normal histopathological findings except $\mathrm{CP}$ seed oil. The rats fed $\mathrm{CP}$ seed oil exhibits inferior growth, low FER and histopathological abnormalities in the liver, probably due to CPFA being present in the oil. In conclusion, since the physicochemical nature and fatty acid composition of the refined seed oils except $\mathrm{CP}$ seed oil are compared well to most common vegetable oils, nontoxic and have good nutritional quality, they can be considered for human consumption while $\mathrm{CP}$ seed oil may not be recommended for edible purpose.
Acknowledgment: Author thanks UGC (University Grants Commission, New Delhi, India) for financial assistance and Biochemistry department of the Burdwan Medical College \& Hospital, Burdwan, WB, India for laboratory support for the feeding experiments.

\section{REFERENCES}

ACHTEN, W.M.J., VERCHOT, L., FRANKEN, Y.J., MATHIJS, E., SINGH, V.P., AERTS, R., MUYS, B., 2008 Jatropha bio-diesel production and use. Biomass Bioenergy, 1063-1084. http://dx.doi.org/10.1016/j.biombioe.2008.03.003.

AGUILAR, N.O., JANSEN, P.C.M., BRINK, M., 2003 Abroma augusta (L.) f. In: Brink M, Escobin RP (eds) Plant resources of South-East Asia No 17 Fibre Plants. Backhuys Publishers, Netherlands, 59-62 p.

ANANDARAJAGOPAL, K., SUNILSON, J.A.J., AJAYKUMAR, T.V., ANANTH, R., KAMAL, S., 2013 In-vitro anti-inflammatory evaluation of crude Bombax ceiba extracts. Eur J Med Plants, 3, 99-104.

AOCS (ed), 1993 Official methods and recommended practices of the American Oil Chemists' Society, $5^{\text {th }}$ edn. Official method Cc 13b-45, reapproved (2000) AOCS, Champaign, IL

ARAFAT, S.M., ESSAM, M.E.K., SAYED, R.M.M., 2011 Fatty acid composition and Quality assurance of semal (Bombax) and monsa (Chorisia) seed oils and use in deep-fat frying. Banat's J Biotechnol, 3, 66-75.

ARI, M.M., BARDE, R.E., OGAH, M.D., YAKUBU, A., AYA, V.E., 2011 Performance of Broilers fed silk cotton (Ceiba pentandra) based diets. PAT, 7 , 20-28.

BRANCO, P.C., CASTILHO, P.C., ROSA, M.F., FERREIRA, J., 2010 Characterization of Annona cherimola mill. seed oil from Madeira Island: a possible biodiesel feedstock. $J$ Am Oil Chem Soc, 87, 429-436. http://dx.doi.org/10.1007/s11746-009-1513-1. 
CHEN, Y., XU, S.S., CHEN, J.W., WANG, Y., XU, H.Q., FAN, N.B., LI, X., 2012 Anti-tumor activity of Annona squamosa seed extract containing annonaceous acetogenin compounds. $J$ Ethnopharmacol, 142, 462-466. http://dx.doi.org/10.1016/j.jep.2012.05.019.

COUNCIL OF SCIENTIFIC AND INDUSTRIAL RESEARCH, 1985 The Wealth of India. CSIR, New Delhi, 513 p.

COVAS, M. I., 2007 Olive oil and cardiovascular system. Pharmacol Res, 55, 175-186. http://dx.doi.org/10.1016/j.phrs.2007.01.010.

COVAS, M. I., KONSTANTINIDOU, V., FITOU, M., 2009 Olive oil and cardiovascular health. $J$ Cardiovascular Pharmacol, 54, 477-482. http://dx.doi.org/10.1097/FJC.0b013e3181c5e7fd.

DIVAKARA, B.N., UPADHYAYA, H.D., WANI, S.P., LAXIMIPATHI, C.L., 2010 Biology and genetic improvement of Jatropha curcas L.: A review. Appl Energy, 87, 732-742. http://dx.doi.org/10.1016/j.apenergy.2009.07.013.

EDITORIAL, 1977 Minor oilseed- a hope for the future. Econ Scene, 2, 27-29.

EISELE, T.A., COULOMBE, R.A., WILlIAMS, J.L., SHELTON, D.W., NIXON, J.E., 1983 Time and dose-dependent effects of dietary cyclopropenoid fatty acids on the mixed function oxidase system of rainbow trout. Aquatic Toxicol, 4, 139-151. http://dx.doi.org/10.1016/0166-445X(83)90051-6.

ELUMALAI, A., NIKHITHA, M., DIDALA, A., KASARLA, R., VENKATESH, Y., 2012 A review on Ceiba pentandra and its medicinal features. Asian J Pharm Technol, 2, 83-86.

FAO/WHO, 2009 Codex alimentarius. Current official standards. http//www.codexalimentarius.net/web/standard-list.jsp Accessed April 2009.

FIORITI, J.A., BENTZ, A.P., SIMS, R.J., 1966 The reaction of picric acid with epoxides. II. The detection of epoxides in heated oils. J Am Oil Chem Soc, 43 487-490. http://dx.doi.org/10.1007/BF02641272.

FRIDAY, E.T., JAMES, O., OLUPINYO, O., GABRIEL, A., 2011 Investigations on the nutritional and medicinal potentials of Ceiba pentandra leaf: a common vegetable in Nigeria. Int J Plant Physiol Biochem, 3, 95-101.

GUPTA, B., NAYAK, S., SOLANKI, S., 2011 Abroma augusta Linn f: a review. Der Pharmacia Sinica, 2, 253-261.

JAIN, V., VERMA, S.K., KATEWA, S.S., 2009 Myths, traditions and fate of multipurpose Bombax ceiba L. - an appraisal. Indian J Trad Knowl, 8, 638-644.

KHAN, T., AHMAD, W., BASHIR, S., IQBAL, Z., AHMAD, B., AHMAD, M. ARFAN, M., SHAHEEN, F., 2003 Biological and pharmacological properties of Abroma augusta Linn. seed oil. Pak J Biol Sci, 6, 1141-1144.

LAKSHMINARAYANA, G., 1969 Applicability of the turbidity test for casto oil to some other hydroxyl and epoxy fatty compounds. J Am Oil Chem Soc, 45 523-524. http://dx.doi.org/10.1007/BF02541340.

LEE, D.J., WALES, J.H., SINNHUBER, R.O., 1971 Promotion of aflatoxininduced hepatoma growth in trout by methyl malvalate and sterculate. Cancer Res, 31, 960-969.

MAGNE, F.C., 1965 Analysis of cyclopropenoid and cyclopropanoid acids in fats and oils. $J$ Am Oil Chem Soc, 42, 332-336. http://dx.doi.org/10.1007/BF02540141.

MAITY, C.R., MONDAL, B., 1990 Chemical and nutritional studies on the seed oil of Acacia Arabica. J Am Oil Chem Soc, 67, 433-434 http://dx.doi.org/10.1007/BF02638955

MARIOD, A.A., ELKHEIR, S., AHMED, Y.M., MALTHAUS, B., 2011 Review: organic foods from Annona squamosa (Gishta) and Catunaregam nilotica (Kirkir). J Sci Technol, 12, 84-91.

MARIOD, A.A., ELKHEIR, S., IDRIS, Y.M.A., MALTHAUS, B., 2010 Annona squamosa and $C$. nilotica seeds, the effect of the extraction method on the oil composition. $J$ Am Oil Chem Soc, 87, 763-769. http://dx.doi.org/10.1007/s11746-010-1548-3.

MASRURI, M., SHARMA, M., WARSITO, W., ALI, P., 2012 Renewable oil extracted from Indonesian Srikaya's (Annona squamosa) seed: another potent source for biodiesel. J Pure Appl Chem Res, 1, 51-57.

MONDAL, B, MAITY, C.R., 1991 Studies on the oil of Mimusopa elengi. Acta Alimentaria, 20, 103-107.

MONDAL, B., GHOSH MAJUMDAR, S., 1984 The component fatty acids of refined Eucalyptus hybrida seed oil. J Sci Res, 6, 19-21.

MONDAL, B., GHOSH MAJUMDAR, S., MAITY, C.R., 1982 Nutritional evaluation of the protein isolate obtained from the seed of Eucalyptus kirtoniana in albino rats- a comparative study. Proc Indian natn Sci Acad, B48, 596-602. MONDAL, B., GHOSH MAJUMDAR, S., MAITY, C.R., 1984a Chemical and nutritional evaluation of Pongamia glabra oil and Acacia auriculaeformis oil. $J$ Am Oil Chem Soc, 61, 1447-1449. http://dx.doi.org/10.1007/BF02636360

MONDAL, B., GHOSH MAJUMDAR, S., MAITY, C.R., 1984b Chemical and nutritional studies on Acacia auriculaeformis seed oil. Indian J Med Res, 80 , 607-610.

MONDAL, B., GHOSH MAJUMDAR, S., MAITY, C.R., 1985a Effect of refined hydrogenated karanja oil on lipid metabolism in adult male albino rats. Acta Alimentaria, 14, 3-13.

MONDAL, B., GHOSH MAJUMDAR, S., MAITY, C.R., 1985b Nutritional study of refined hydrogenated eucalyptus seed oil. J Oil Technol Assoc India, 17, $1-13$.

MONDAL, B., MAITY, C.R., 1983 Nutritional evaluation of some vegetable proteins. Ann Natl Acad Med Sci India, 19, 194-206.
MONDAL, B., MAITY, C.R., 1992 Physicochemical and nutritional characteristics of Michelia champaca seed oil. Acta Alimentaria, 21, 131-135.

MUKHTAR, M.A., 2007 The effect of feeding Rosella (Hibiscus sabdariffa) seed on Broiler chick's performance. Res J Anim Vet Sci, 2, 21-23.

NAHAR, L., RIPA, F.A., ZULFIKER, A.H., ROKONUZZAMAN, M.D. HAQUE, M., ISLAM, K.M.S., 2010 Comparative study of antidiabetic effect of Abroma augusta and Syzygium cumini on alloxan induced diabetic rat. Agric Biol $J$ N Am, 1, 1268-1272. http://dx.doi.org/10.5251/abjna.2010.1.6.1268.1272.

NATARAJAN, E., KARTHICK, V.P., 2012 Production and characterization of biodiesel using Pongamia oil by immobilized Rhizopus oryzae. Adv Biotechnol, $11,32-36$

NORAZAHAR, N., YUSUP, S., AHMAD, M.M., ABUBAKAR, S., AHMAD J., 2012 Parametric optimization of kapok (Ceiba pentandra) oil methyl ester production using Tagnchi approach. Int J Energy Environ, 6, 541-548.

OILS AND FATS SUBCOMMITTEE, 1984 Indian standard criteria for edibility of oils and fats. IS, 11068-1984.

ORTINAU, L.C., NICKELSON, K.J., STROMSDORFER, K.L., NAIK, C.Y., PICKERING, R.T., HAYNES, R.A., FRITSCHE, K.L., PERFIELD, J.W., 2013 Sterculic oil, a natural inhibitor of SCDI, improves the metabolic state of obese OLETF rats. Obesity 21, 344-352. http://dx.doi.org/10.1002/oby.20040.

PANDEY, N., BARVE, D., 2011 Phytochemical and pharmacological review on Annona squamosa Linn. Int J Res Pharmac Biomed Sci, 2, 1404-1412.

RUKMINI, C., VIJAYARAGHAVAN, M., TULPULE, P.G., 1982 Nutritional and toxicological evaluation of Hibiscus sabdariffa oil and Cleome viscose oil. $J$ Am Oil Chem Soc, 59, 415-419. http://dx.doi.org/10.1007/BF02634425.

SAHA, R., 2011 Pharmacognosy and pharmacology of Annona squamosa - a review. Int J Pharm Lf Sci, 2, 1183-1189.

SALIMON, J., KADIR, K.A.A., 2005 Fatty acid composition and physicochemical properties in kekabu seed oil. Sains Malaysiana, 34, 117-120.

SARKIYAYI, S., IBRAHIM, S., ABUBAKAR, M.S., 2009 Toxicological studies of Ceiba pentandra Linn. Afr J Biochem Res, 3, 279-281.

SHONE, G.G., 1966 Adverse effects of cyclopropenoid fatty acids. Proc Nutr Soc, 25, 37-44.

SINGH, M.P., PANDA, H., 2005 Medicinal herbs and their formulations. Vol I, Daya Publishing House, New Delhi, 176-178 p.

SUB-COMMITTEE ON MINOR OILSEEDS, 1971 Report of the SubCommittee on minor oils seed. Ministry of Agriculture, Govt of India, New Delhi, $4 \mathrm{p}$

VERMA, V., JALALPURE, S.S., SAHU, A., BHARDWAJ, L.K., PRAKASH Y., 2011 Bombax ceiba Linn: Pharmacognostical, phytochemistry, ethnobotany and pharmacology studies. Int Pharmac Sci, 1, 62-68.

VIDYASAGAR, G.M., SINGH, S.P., 2012 A comparative antimicrobial activity of methanolic root, leaf, seed cotyledon extracts of Annona squamosa L. Int J Pharm Pharmacol Sci, 4(Suppl 5), 289-292.

VIMAL, O.P., NAPHADE, K.T., 1980 Utilization of non-edible oilseeds-recent trends. J Sci Indust Res, 39, 